the reduction process leads to a positive error" are totally unsupported by experimental evidence.



\title{
AN APPARATUS FOR ABSOLUTE ALCOHOL.
}

\author{
BY W. H. WARREN. \\ Received March I2, 1910.
}

Freshly prepared absolute alcohol is more reliable than the article supplied by dealers and much cheaper. One never feels quite sure without making a test that he is getting an alcohol which is really absolute. For preparing small quantities of this solvent there is no need of suggesting any modification of the usual procedure of boiling ordinary alcohol over burnt lime in a glass flask under a return-condenser and distilling.



But large classes of students of ten require considerable absolute alcohol, the preparation of which has to be left to persons more or less inexperienced. Under these conditions there is frequent breakage of glass together with loss of alcohol, and another form of apparatus is desirable. For some time the apparatus shown in the drawing has given satisfactory results in this laboratory. It is constructed of coppe and was made according to specification by the firm of Eimer and Amend, New York. A tinsmith can make a less ex-

pensive apparatus of heavy tin which will answer every purpose.

The outer flanged copper vessell $A$ has an inside diameter of $28 \mathrm{~cm}$. and is $30 \mathrm{~cm}$. high. It is tinned on the inside and the bottom is reinforced on the outside with iron for protection against heat. This vessel serves as a water-bath in which water is kept at constant level by means of the side tubulus $a_{1}$ provided with the overflow pipe $a_{2}$. The water which passes through condenser $D$ runs into $a_{1}$. Several openings $a_{3}$ at the top allow steam to escape. This bath rests upon bricks and heat is applied from the Fletcher burner $F$.

Within $A$ and resting quite free upon its flange is a second flanged 
copper vessel, $B$. Except for the opening $b_{1}$ for introducing burnt lime and alcohol, this inner vessel is closed. It is $24 \mathrm{~cm}$. in diameter and 28 $\mathrm{cm}$. high to the flange. The diameter of the opening $b_{1}$ is $57 \mathrm{~mm}$. When filled with burnt lime, $B$ holds about rine liters of commercial grain alcohol.

A brass $\mathrm{Y}$-tube $C$ passes through a rubber stopper in $b_{1}$. The arm $c_{1}$ is straight and somewhat widened at the top to admit the rubber stopper connecting it with condenser $D$, but the arm $c_{2}$ is bent at an obtuse angle. On each arm beyond the point of divergence is a cock $c_{3}$ and $c_{4}$. The internal diame ter of these tubes is $15 \mathrm{~mm}$., but a somewhat larger bore would be an advantage. Of especial importance is the bore of the cock which should be the same as that of the tube. If the bore of the brass tube is too small, or the cock has a smaller bore than that of the tube, alcohol will collect in the condenser during dehydration.

Condenser $D$ is connected with the top of $c_{1}$ by a rubber stopper. It should be long enough to cool well during dehydration and its bore should not be too small. Condenser $E$, connected with $c_{2}$ by a rubber stopper, is in the usual position for distilling.

By closing cock $c_{4}$ and opening cock $c_{3}$, alcohol can be boiled until dehydrated. It is well to watch the apparatus closely until boiling proceeds quietly. If heated too rapidly, or if the still is too full, alcohol is apt to start boiling so violently that it will be ejected from the top of the condenser. But this occurrence can be avoided by raising the temperature gradually. When boiling begins, the flame can be adjusted and further attention is unnecessary.

By closing cock $c_{3}$ and opening cock $c_{4}$, a test portion of alcohol may be distilled at any time and its specific gravity determined. If dehydration is incomplete, the test portion may be returned through the top of the condenser. By reversing the cocks, boiling may be continued until a sample having a satisfactory specific gravity is obtained. Finally, when dehydration is complete, distillation may be begun without first cooling the alcohol. Of course all precautions should be taken to keep the distillate from absorbing moisture from the air.

A change in the construction of the still, which would probably be an improvement, may be suggested. When distillation begins and for some time after, alcohol comes over readily, but toward the end it distils slowly. Undoubtedly this is due to the size of the still, which, though well heated on the side and bottom, is not so on the inside. If four or five tubes, closed at the upper and open at the lower end, were to project from the bottom into the interior of the still, the boiling water in these tubes would convey heat into the mass of alcohol and lime and hasten distillation.

Several experiments were made with this apparatus to determine 
how long to boil alcohol over lime before distilling. I have heard instructors advise half an hour's boiling as sufficient, whereas others have insisted that boiling over lime should be continued for a day at least. The tests $I$ have made with this apparatus would seem to indicate that the longer rather than the shorter boiling is advisable. In making these tests there was no intention of entering upon an investigation of absolute alcohol, but merely of determining the proper conditions for preparing absolute alcohol for laboratory purposes so that definite directions might be given to an assistant having charge of such work.

A pycnometer holding $50 \mathrm{cc}$. was used in determining all specific gravities. The weight of pure water at $15^{\circ} \mathrm{C}$. was first determined in this apparatus and then the weight of an equal volume of alcohol at the same temperature. Specific gravities were compared with those given by Squibb and percentages were calculated from his tables.

Experiment 1 .-Small pieces of burnt lime were put into the still to within an inch of the flange, and covered with nine liters of commercial grain alcohol. This alcohol is said to contain 188 per cent. of proof spirit. Its specific gravity was found to be $0.8198(=91.04$ per cent. by weight). Before being heated, the alcohol stood in contact with lime for twenty-four hours. At the end of that time heat was applied and from the moment the alcohol began to boil, a test portion (about $250 \mathrm{cc}$.) was distilled every fifteen minutes and its specific gravity determined. The results of these tests are given in the following table:

\begin{tabular}{|c|c|c|c|}
\hline No. & $\begin{array}{l}\text { ime of boiling } \\
\text { it hours. }\end{array}$ & $\begin{array}{l}\text { Sp.gr. at } 15^{\circ} \\
\text { by pycnometer. }\end{array}$ & $\begin{array}{l}\text { Per cent. of al- } \\
\text { cohol by weight }\end{array}$ \\
\hline $\mathbf{I} \ldots \ldots \ldots \ldots \ldots$ & 0.25 & 0.7988 & $98.4 \mathrm{I}$ \\
\hline $2 \ldots \ldots \ldots \ldots \ldots \ldots$ & 0.5 & 0.7972 & $98.9 I$ \\
\hline$\ldots \ldots \ldots \ldots$ & 0.75 & 0.7965 & 99.13 \\
\hline $4 \ldots \ldots \ldots \ldots$ & 1.0 & 0.7958 & $99 \cdot 3.5$ \\
\hline $5 \ldots \ldots \ldots \ldots \ldots$ & I. 25 & 0.7952 & 99.55 \\
\hline $6 \ldots \ldots \ldots \ldots \ldots \ldots$ & 1.5 & 0.7950 & $99.6 I$ \\
\hline $7 \ldots \ldots \ldots \ldots \ldots$ & I. 75 & 0.7949 & 99.65 \\
\hline $8, \ldots \ldots \ldots \ldots \ldots$ & 2.0 & 0.7945 & 99.77 \\
\hline
\end{tabular}

Most of the alcohol after the eighth sample, which contained 99.77 per cent., was distilled into a large bottle. Its specific gravity was 0.7943 ( $=99.84$ per cent.). The final $500 \mathrm{cc}$. of alcohol was collected by itself and had a specific gravity of $0.7940(=99.94$ per cent.). Nine liters of 9r.04 per cent. commercial grain alcohol usually yield about six liters of absolute alcohol which will vary slightly in strength depending upon the length of time the alcohol is boiled over lime. From these tests the conclusion was drawn-and this conclusion was confirmed by later teststhat two hours' boiling is by no means sufficient to get the best possible absolute alcohol.

Experiment 2.-Nine liters of commercial alcohol were placed in the still with lime, and boiled for two hours without being allowed to stand 
as in the first experiment. At the end ot that time a sample of alcohol was distilled and tested. This was repeated at the end of each succeeding hour and the results are given in the following table:

\begin{tabular}{|c|c|c|c|}
\hline $\mathrm{Ti}$ & $\begin{array}{l}\text { ime of boiling } \\
\text { in hours. }\end{array}$ & $\begin{array}{c}\text { Sp.gr.at } 15^{\circ} \\
\text { by pycnometer. }\end{array}$ & $\begin{array}{l}\text { Per cent. of al- } \\
\text { cohol by weight. }\end{array}$ \\
\hline I................ & . 2 & 0.7964 & 99.16 \\
\hline $2 \ldots \ldots \ldots \ldots$ & . & 0.7954 & $99 \cdot 4^{8}$ \\
\hline $3 \ldots \ldots \ldots \ldots$ & . & 0.7944 & $99.8 I$ \\
\hline $4 \ldots \ldots \ldots \ldots$ & . & 0.7943 & 99.84 \\
\hline $5 \ldots \ldots \ldots \ldots \ldots$ & 6 & 0.7942 & 99.87 \\
\hline $6 \ldots \ldots \ldots \ldots \ldots$ & . & $0.794^{2}$ & 99.87 \\
\hline $7 \ldots \ldots \ldots \ldots$ & 8 & 0.7942 & 99.87 \\
\hline
\end{tabular}

The experiment had to be stopped at the end of the eighth hour. The remainder of the alcohol stood in contact with lime about 30 hours when boiling was resumed. At the end of an hour's boiling a sample was taken and found to have sp. gr. $0.7942(=99.87$ per cent.). From this experiment it would appear that when the alcohol reaches the point where it gives a distillate containing 99.87 per cent., it remains constant. This point in this experiment was reached after six hours' boiling. Yet the mass of the alcohol shows a higher percentage, for most of the alcohol as in the first experiment was collected in a large bottle and had a specific gravity of 0.7940 ( $=99.94$ per cent.). The final portion of distillate was collected by itself but its specific gravity was the same as that of the main sample.

Experiment 3.-The two preceding experiments show that alcohol after twenty-four hours standing over lime will give a distillate at the end of two hours' boiling, containing 99.77 per cent.; whereas the same alcohol that has not stood will give, after being boiled two hours, a distillate containing 99.I6 per cent. This seemed to indicate that previous standing over lime might be of advantage. This experiment was made to see if this is the case.

Nine liters of alcohol stood over lime twenty-four hours. At the end of that time the alcohol was boiled two hours and then tested. A test was also made at the end of each succeeding hour with the results given in the following table:

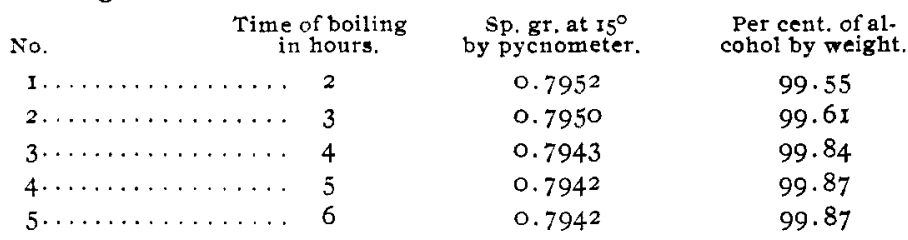

From this experiment it would appear that alcohol, which has previously stood over lime, can be brought to the point where it will give a distillate having a constant specific gravity sooner than it can if not 
allowed to stand; but the difference in time is so slight that there is no advantage in the previous standing.

Experiment 4.-The quantity of burnt lime in the preceding experiments is much in excess of that theoretically needed to take up the water present. Consequently, the yield of absolute alcohol is not as high as it would be if less lime were used. In the hope of increasing the yield without lowering the strength of the alcohol, I made two tests conducting dehydration in two stages and each test gave essentially the same result.

Nine liters of commercial alcohol were boiled for six hours over 2 roo grams of burnt lime. This is slightly more lime than is required to take up the water. The specific gravity of a sample of alcohol at the end of six hours' boiling was $0.8006(=97.83$ per cent. $)$ and that of the entire distillate was $0.7980(=98.66$ per cent. $)$. The total distillate measured $7450 \mathrm{cc}$.

I then returned the $745^{\circ} \mathrm{cc}$. of partially dehydrated alcohol to the still with 300 grams of burnt lime, a quantity slightly in excess of that theoretically needed to combine with the water. The specific gravity of the total distillate after six hours' boiling was $0.7970(=98.97$ per cent.) and it measured about $7300 \mathrm{cc}$.

The yield of absolute alcohol by this method is much better but twice as much time is required and the alcohol, though sufficiently good for most purposes, is by no means as nearly absolute as it is after one treatment with a large excess of lime.

\section{Summary.}

I. It is not possible to deprive commercial alcohol of all its water by boiling over lime. Dehydration takes place gradually up to a certain point and it is useless to boil longer under return-condenser when the testdistillate contains 99.87 per cent.

2. Commercial alcohol can be brought to the point where it will give a test-distillate containing 99.87 per cent. by boiling six hours without previous standing over lime; or, by boiling five hours, after allowing the alcohol to stand for twenty-four hours over lime.

3. When the test-distillate contains 99.87 per cent., the alcohol, if distilled, will contain as a whole 99.94 per cent. I have never succeeded in getting a distillate containing a higher percentage of alcohol than this.

4. It is possible to increase the yield of absolute alcohol by conducting the dehydration in two stages and using each time a quantity of lime only in slight excess of that theoretically required to combine with the water present. But the absolute alcohol obtained will by no means be as strong as it will be if dehydration takes place at one operation in presence of a large excess of lime.

WASEINGTON UNIVERSITY MEDICAL SChOOL, 